\title{
Procedural Factors Influencing Forest Certification Audits: An Empirical Study in Romania
}

\author{
Aureliu-Florin Hălălișan ${ }^{1}\left(\mathbb{D}\right.$, Bogdan Popa $^{1, * \mathbb{C}}$, Iñaki Heras-Saizarbitoria ${ }^{2}$, Olivier Boiral $^{3}$, \\ Germán Arana-Landín ${ }^{4}{ }^{\mathbb{D}}$, Adelin-Ionuț Nicorescu ${ }^{5}{ }^{-}$and Ioan Vasile Abrudan ${ }^{5}$
}

1 Department of Forest Engineering, Faculty of Silviculture and Forest Engineering, Transilvania University of Brasov, Sirul Beethoven Street, no. 1, 500123 Brasov, Romania; aureliu.halalisan@unitbv.ro

2 Department of Management, Faculty of Economics and Business, University of the Basque Country, Plaza Oñati 1, 20018 San Sebastian, Spain; inaki.heras@ehu.eus

3 Department of Management, Faculty of Business Management, Laval University, Pavillon Palasis-Prince, 2325, rue de la Terrasse, Local 1638, Québec, QC G1V 0A6, Canada; Olivier.Boiral@mng.ulaval.ca

4 Department of Management, Faculty of Engineering, University of the Basque Country, Plaza de Europa 1, 20018 San Sebastian, Spain; g.arana@ehu.eus

5 Department of Silviculture, Faculty of Silviculture and Forest Engineering, Transilvania University of Brasov, Sirul Beethoven Street, no. 1, 500123 Brasov, Romania; adelin.nicorescu@student.unitbv.ro (A.-I.N.); abrudan@unitbv.ro (I.V.A.)

* Correspondence: popa.bogdan@unitbv.ro

Citation: Hălălișan, A.-F.; Popa, B.; Heras-Saizarbitoria, I.; Boiral, O.; Arana-Landín, G.; Nicorescu, A.-I.; Abrudan, I.V. Procedural Factors Influencing Forest Certification Audits: An Empirical Study in Romania. Forests 2021, 12, 172 https://doi.org/10.3390/f12020172

Academic Editor: Hubert Paluš Received: 29 December 2020

Accepted: 31 January 2021

Published: 2 February 202

Publisher's Note: MDPI stays neutra with regard to jurisdictional claims in published maps and institutional affiliations.

Copyright: (c) 2021 by the authors. Licensee MDPI, Basel, Switzerland. This article is an open access article distributed under the terms and conditions of the Creative Commons Attribution (CC BY) license (https:/ creativecommons.org/licenses/by/ $4.0 /)$

\begin{abstract}
In the recent decades, forest certification based on third-party external audits has gained momentum. This type of certification has been developed as a monitoring tool aimed at improving governance in corporate environmental management and differentiating products in the increasing environmentally sensitive markets. Although the scholarly literature has extensively analyzed the adoption and dissemination of forest certification, the findings of the external audits and certification practices remain under researched. On the basis of the analysis of 105 audit reports issued by accredited third-party certification bodies in Romania, this article sheds light on procedural factors that have significant influence on the characteristics of non-conformities (NCs) identified by Forest Stewardship Council (FSC) third party audits. Our research offers empirical evidence that certain procedural factors such as the type of assessment, auditing days, number of auditors, or the presence of foreign members in an audit team have a significant influence on the auditing process outcomes: number and grade of non-conformities, standard references, or methods of NC detection. The study opens interesting new lines of research-the influence of procedural or other types of contextual factors on certification outcomes-and provides indications on the effectiveness of the certification procedures and guidelines in certification process quality assurance.
\end{abstract}

Keywords: forest certification; FSC; forest management; audits; non-conformities; Romania

\section{Introduction}

Forest certification is a voluntary process based on consumer preference for wood products sourced from sustainably managed forests. The performance of forest management organizations is evaluated by an independent third-party (external audits) to determine whether forest management satisfies ecological, economic, and social requirements pre-established by a standard [1]. Forest certification has become a strategic instrument for business, particularly for entities that sell their certified products in environmentally sensitive markets [2-6]. In many cases, after certification, the wood-based production entities can receive benefits such as good reputation, increased market share, access to new markets, or price premium [7-10].

The Forest Stewardship Council (FSC) and The Programme for the Endorsement of Forest Certification (PEFC) are the most popular voluntary forest certification schemes. Thus far, over 220 million hectares of forestland have been FSC-certified in over 80 countries 
worldwide [11,12] and over 320 million hectares of forest land are certified under the PEFC scheme in 40 countries [13]. FSC and PEFC certification is achieved through an auditing process carried out by an independent accredited certification body, with forest management conformity assessed against the standard $[1,12,13]$-FSC has one set of principles and criteria defined by FSC International or defined by regional working groups coordinated by national chapters [14]; PEFC, on the other hand, is based on the standards developed by each country, evaluated by PEFC International under certain requirements [15].

The specific requirements of FSC and PEFC standards aim to continuously improve forest management and involve all relevant stakeholders. These schemes focus on compliance with national and international legislation or good practices [16], clarification of ownership issues, development of forest management plans aimed at preserving and enhancing conservation attributes, increasing safety of forest-specific activities, and ensuring optimal work conditions and transparency. Regarding benefits, certified entities mainly consider forest certification as a tool for improving external company image, promoting sustainable utilization of forest resources, and improving forest management practices [17].

The scientific literature has extensively analyzed the adoption and dissemination of FSC certification, focusing, among other aspects, on the motivations for forest certification $[9,18]$ and the impact of its adoption [9,18-24]. Moreover, the interest in studying the non-conformities (NCs) resulting from forest certification audits has increased the scientific literature providing interesting insights on the type of NCs related to the FSC principles [25-28]. Rafael et al. [28] explored the main challenges faced by companies from Brazil in the FSC certification process, analyzing the quantity, spatial distribution, noncompliant principles, potential triggers, and thematic areas of non-conformities. In Mexico, Blackman et al. [25] found that most of the corrective action requests addressed minor procedural issues and focused on social, economic, and legal issues, not on-the-ground environmental ones. A deep procedural analysis was performed by Hermundanado et al. in Indonesia [26], revealing that the clear majority of NCs issued to FSC-certified units were minor and required only procedural changes. Regarding the requirements of standards, Piketty and Drigo [27] analyzed the objectivity of indicators and showed that some indicators were difficult to check through an audit procedure.

The whole voluntary forest certification construction relies heavily on the capacity of the certification schemes to provide independent assessment, which is not affected by subjectivity. Despite the special attention given by the researchers to forest certification, there are very few studies scrutinizing the procedural factors and their impact on forest certification quality. On the basis of these studies, and also on studies focusing on other certification schemes under the International Organization for Standardization (ISO) $[9,26,29-31]$, we are able to identify a set of procedural factors as having the potential to influence the quality of third-party external audits: the type of assessment, the sampling process of verified aspects, the audit period, the composition and the profile of the auditing teams (auditor background, number of auditors, presence of foreign auditors in the team), and the presence of accreditation body witnessing the assessment. An empirical analysis of the relationship between these factors and the audit results may lead to interesting outcomes that can trigger discussions regarding the effectiveness of auditing procedures in eliminating the influence of the procedural factors. This has been the case for other more disseminated third-party certification schemes such as ISO 9001 and ISO 14001 certifications [31-34]. However, with regard to these certification schemes, as underlined by Heras-Saizarbitoria and Boiral [34], the key issues (i.e., the misconceptions of the certification and auditing practices for sustainability) of the independent external audits have been surprisingly overlooked, with very few exceptions, e.g., [31,32,35]. The findings of these works pointed out a set of procedural factors that impact on the results of external audits. In their empirical work carried out in Canada, on the basis of interviewing ISO 14001 auditors, Heras-Saizarbitoria et al. [31] underlined the importance of some procedural factors such as the duration of the audit, the information supplied by organizations, and the characteristics and the role of the auditor. Similarly, Biazzo [35] highlighted the 
importance of the role adopted by auditors in the case of the Italian companies. In the work by Sampaio et al. [32] developed in Portugal and based on the analysis of ISO 9001 audit reports, factors such as the number and type of the non-conformities were found to be relevant, as pointed out also by Karapetrovic and Willborn [36] in their seminal theoretical paper about the effectiveness of audit systems for quality assurance. Finally, on the basis of their empirical work carried out in Italy, Chiarini and Vagnoni [37] identified a set of key factors for an audit, such as auditors' skills, the use of standardized checklists, and the type of assessment (e.g., scheduled or not).

When the findings of the literature focused on FSC certification and the literature focused on other certification schemes are considered, the following research question arises: Do procedural factors influence the characteristics NCs identified by FSC thirdparty audits?

Starting from the formulated research question, the aim of this paper was to explore the procedural factors influencing the auditing process and outcome through an empirical analysis of FSC auditing reports in Romania. Such an analysis can support the identification of measures to improve forest certification procedures in order to increase the auditing legitimacy, impartiality, and objectivity.

This paper was structured in six sections, including this introduction. The following section presents the FSC procedures and Romanian context, followed by methodology (Section 3). The fourth section presents the results of the analysis and its most relevant descriptive and inferential statistics. Section 5 discusses the findings, and Section 6 finally draws concluding remarks and highlights future avenues of research.

\section{Background of FSC Auditing Process and Romanian Forest Certification Context}

\subsection{FSC Auditing Process}

The certification process quality assurance is one of the main concerns of the certification schemes. They aim to standardize the auditing procedures in order to reduce the possible influence of procedural factors and enhance the legitimacy and impartiality in the certification process [38-41]. Possible subjective aspects of verification such as auditing periods or auditing teams' features are the subject of procedural standardization [42-45]. The forest certification schemes are no exception-the quality assurance process recognizes that clear and objective procedures, among other factors, are important for achieving and assuring quality.

For the FSC scheme, the certification bodies have developed detailed procedures for certification process quality assurance. Various measures, including internal procedures for auditors' assessment, selection, and training, are designed and implemented aiming at improving the impartiality of the process and limiting the influence of procedural factors on the auditing outcomes. The FSC standard 20-001 [12] defines the requirements related to the auditing teams. They must have a leading auditor with the ability to conduct the audit and collect the evidence, one auditor from the team must be fluent in the main language used in the area, and the team must include at least one technical expert with the necessary experience and qualifications to audit all aspects of the FSC principles and criteria for forest management, considering the scale and complexity of the certified area to be assessed [12]. The FSC auditing time is also regulated by the FSC standards and directive [46,47]—it varies with the number of audited units; management complexity; social and environmental conditions; number of evaluated field sites; and number of records, documents, and interviewed stakeholders [46]. Audits are classified as follows: main assessments (MAs), surveillance assessments (SAs), and re-assessments (RAs). The FSC directive [47] offers clear provisions regarding the auditing time, depending on the type of assessment. For instance, an area of 5000-10,000 ha requires 3 auditing working days for MAs, 1.5 days for SAs, and 2.5 days for the RAs. The auditing time can be reduced (to minimum 1 day for MAs and RAs and 0.5 days for SAs) on the basis of the forest type (for plantations, the time can be reduced by $30 \%$ ), extension of forestry activities, complexity of management system, etc. The auditing time can also be increased, within 
certain limits, depending on the infrastructure, stakeholder's context and complaints, open NCs, assessment of high conservation values forests, etc. [47].

In the FSC scheme, the focus of the audits is on detecting any failure of audited entity against certification standards. These FSC failures (the non-conformities) are classified as minor or major [46]. An NC is considered minor if it is a temporary, non-systematic lapse, with temporally and spatially limited impacts [46]. Minor NC identification does not result from a fundamental failure to achieve the objective of the relevant FSC criterion or another applicable certification requirement [46]. An NC is considered major if, either alone or in combination with other NCs, it results in, or is likely to result in, a fundamental failure to achieve the objectives of the relevant FSC criterion, or affects a significant part of the applied management system. Minor NCs shall be fully corrected within 1 year and major NCs shall be fully corrected within 3 months [46].

During the certification audits, for every entity entering the process, the auditors must identify and assess the management documentation and a sufficient variety and number of records to allow making direct, factual observations that would clearly reveal the conformity with indicators of the applicable standard [46]. Moreover, field visits and confidential stakeholders' consultations are conducted. Once issued, the FSC forest management certificate is valid for 5 years, with annual audits aimed at verifying the compliance with FSC requirements. All audits are undertaken independently, meaning that auditors can identify NCs during all types of assessments [12]. In MAs and RAs, all indicators must be assessed and consequently more NCs can be identified. In SAs, the auditors shall review any changes of the forest area included in the scope of the certificate, changes to the certificate holder's management system, received complaints, work-related accident records, training records, inventory records, harvesting records, chemical use records, certified products sale records, etc. [46]. Moreover, in SAs, only a sample of the FSC principles is to be systematically assessed [46]. The FSC certificate is issued after the MA and is followed by several SAs in the first certification cycle. After that, in the second cycle, the certification body may re-issue a certificate that has expired, on the basis of the reevaluation of the certificate holder's conformity with all aspects of the applicable FSC and additional (e.g., contractual) certification requirements. During the SAs and RAs, NCs can be upgraded from minor to major, and this can conduct to certificate suspension [46].

FSC standard for forest management evaluations (FSC-STD-20-007) requires all NCs that are identified by the certification body during an evaluation to be systematically recorded in the evaluation report or associated checklists [46]. Assurance System International (ASI) is the accreditation body involved in the FSC certification scheme and its role is to check how sustainability standards are implemented on the ground [48] by reviewing the procedures of the certification body and assessing the audits performed by the auditors. Annually, ASI verifies the complaints and selects a sample of audits to evaluate the certification bodies.

\subsection{Forest Certification in Romania}

Forest certification in Romania represents a relevant area of study due to the magnitude and complexity of the forestry sector [49-52] and the two decades' history of forest certification (FSC is the only forest certification scheme in the country, and the first forest area was certified in 2002). More than 2.8 million ha (33 FSC active certificates) have been certified under the FSC scheme, and more than 800 companies have obtained the chain of custody certificate [11]. NCs identified in the FSC certification process in Romania have been studied according to their typology [53] and also from a legal perspective [54]. The most frequently identified NCs in the certification process are related to environmental impact $(34 \%)$, community relations and workers' rights $(17 \%)$, and monitoring and assessment (13\%) [53]. The NCs related to FSC principles 4, 6, and 9 appeared to be significantly influenced by the specificity of the country economic development [53]. The very prescriptive legislation governing the forest sector in Romania [52,55] has triggered some particularities of the certification process-more than half of the identified NCs between 2006 and 2018 
were assessed as legal correction action requests, meaning that they represent a problem that in fact violates a legal requirement [54].

\section{Methods}

The empirical analysis of the relationship between the procedural factors that can influence the forest certification auditing process and the resulting NCs was undertaken for all FSC forest management certificates issued for Romanian forests between 2006 and 2018. All public official reports on FSC forest management certification implementation in Romania were extracted from the existing public platform [56], and information (presented in Table 1) was used in the analysis. A total of 105 reports from different types of assessments, drafted by 3 certification bodies, were considered, and all 456 identified NCs (431 minor and 25 major) for all FSC active certificates at the beginning of 2019 were analyzed. Type, grade, and standard reference (FSC principles) of identified forest management NCs against the FSC standard were recorded in an MS Office EXCEL database, and the distributions of the identified non-conformities were traced and quantified.

Table 1. Variables use for analysis.

\begin{tabular}{|c|c|c|c|}
\hline Variables & Description of Variables & Type & \\
\hline Year of certification for audited entities & Year of issuing the certificate & \multirow{2}{*}{ Audited entity variables } & \multirow{7}{*}{ Independent } \\
\hline Area & Area under the scope of certification & & \\
\hline Type of assessment & MAs, SAs, RAs & \multirow{5}{*}{ Audit procedure variables } & \\
\hline Number of days & Auditing days on site location & & \\
\hline Number of auditors & Audit team members & & \\
\hline Foreign members & Auditors from other countries & & \\
\hline ASI witness assessment & Presence of accreditation body & & \\
\hline Nonconformities & Results/findings of audit & \multirow{4}{*}{$\begin{array}{l}\text { Audit findings variables } \\
\text { (outcomes) }\end{array}$} & \multirow{4}{*}{ Dependent } \\
\hline Grade of nonconformities & Major-minor & & \\
\hline Standard reference & FSC principles & & \\
\hline NCs method of detection & $\begin{array}{l}\text { Document verification, field checks, } \\
\text { or stakeholders' interviews }\end{array}$ & & \\
\hline
\end{tabular}

The database also included how the NCs were identified (document verification, field checks, or stakeholders' interviews). In accordance with the stated possible influencing procedural factors, we identified several variables in the public reports regarding certified area, the certification year for audited entities (year when the certificate was issued), the assessment type, the number of auditors in the audit team, the number of audit days, and the ASI evaluations.

Non-parametric statistical differences, correlations, and regressions were performed using SPSS-V.26 statistical package. The Mann-Whitney $U$ test was applied to detect the differences between 2 groups (e.g., analysis of the NCs identified according to the participation of foreign members and ASI witnesses in the auditing team), while the differences between several groups were tested using the Kruskal-Wallis analysis of variance (ANOVA) method (e.g., analysis of the NCs detected according to the type of assessment), all with a transgression probability of $p=0.05$ and $p=0.01$. The Spearman correlations between the number of minor, major, and total NCs, and both the audited entity variables and the audit process variables were tested. Specifically, the audited entity variables were the year of certification (codes 1 to 11) and the certified forest area. The audit process variables were the type of assessment (1-code for MA, 0 - code for the other types of assessment), the number of audit days, the number of auditors, participation of foreign auditors in the audit team, and the ASI witness participation (1-code for participation, 0 —code for no participation). 
The 3 dependent variables (total number of NCs, number of major and minor NCs) were included in a two-step multiple regression (Table 1). The independent variables that were considered in the regression analysis were, in the first step, the audited entity variables and, in the second step, the audit procedure variables (Table 1). No constant was included in the analysis since, in this way, $R^{2}$ would be significantly increased.

\section{Results}

\subsection{Descriptive Statistical Analysis of NCs}

The type of assessment can influence the number of identified NCs, since in MAs and RAs, all indicators must be assessed, while in SAs, a sampling approach is used. Depending on the type of assessment, we distributed the 456 NCs as follows: 224 NCs in $26 \mathrm{MA}$ reports, $21 \mathrm{NCs}$ in 7 first RA reports, $1 \mathrm{NC}$ in $1 \mathrm{~s}$ RA report, and the remaining 210 NCs in 60 SA reports. The average number of identified NCs per assessment was 4.3. In the case of MAs, the average number of NCs per assessment was significantly higher (8.6), while in the case of SAs, the average was 3.0 NCs per assessment, and for Ras, the average was $2.5 \mathrm{NCs}$ per assessment (Table 2).

Table 2. Descriptive statistics of the analyzed assessment reports and non-conformities (NCs).

\begin{tabular}{|c|c|c|c|c|c|c|}
\hline $\begin{array}{c}\text { Year of } \\
\text { Certification for } \\
\text { Audited Entities }\end{array}$ & $\begin{array}{c}\text { Type of } \\
\text { Assessment }\end{array}$ & $\begin{array}{l}\text { Assessment } \\
\text { Code }\end{array}$ & $\begin{array}{l}\text { Minor NCs } \\
\text { Average } \\
\text { Number }\end{array}$ & $\begin{array}{c}\text { Major NCs } \\
\text { Average Number }\end{array}$ & $\begin{array}{l}\text { NCs Average } \\
\text { Number }\end{array}$ & $\begin{array}{c}\text { Number of } \\
\text { Reports }\end{array}$ \\
\hline 1 & Main assessment & MA & 8.35 & 0.27 & 8.61 & 26 \\
\hline 2 & Surveillance 1 & S1 & 3.25 & 0.15 & 3.40 & 20 \\
\hline 3 & Surveillance 2 & $\mathrm{~S} 2$ & 2.32 & 0.21 & 2.53 & 19 \\
\hline 4 & Surveillance 3 & S3 & 2.67 & 0.67 & 3.33 & 12 \\
\hline 5 & Surveillance 4 & $\mathrm{~S} 4$ & 2.78 & 0.22 & 3.00 & 9 \\
\hline 6 & Re-assessment 1 & RA1 & 2.86 & 0.14 & 3.00 & 7 \\
\hline 7 & Surveillance 1 & S1-RA1 & 2.75 & 0.00 & 3.75 & 4 \\
\hline 8 & Surveillance 2 & S2-RA1 & 1.67 & 0.00 & 1.67 & 3 \\
\hline 9 & Surveillance 3 & S3-RA1 & 3.00 & 0.00 & 3.00 & 2 \\
\hline 10 & Surveillance 4 & S4-RA1 & 2.50 & 0.00 & 2.50 & 2 \\
\hline \multirow[t]{2}{*}{11} & Re-assessment 2 & RA2 & 1.00 & 0.00 & 1.00 & 1 \\
\hline & Total & & 4.10 & 0.24 & 4.34 & 105 \\
\hline
\end{tabular}

In the first cycle of certification (26 MA reports and $60 \mathrm{SA}$ reports), the average number of identified NCs was higher (4.7) when compared with the second cycle-2.7 NCs per report (in 7 first RA reports and 11 SA reports) (Table 3). A number of 381 out of the 429 minor NCs $(89 \%)$ was identified in the first cycle (the number of reports of the first cycle was $86(82 \%))$. For the MA reports, the average number of minor NCs per report (8.35) was higher than for the RA reports (2.86) (Table 2). Regarding the major NCs, in the first cycle, 24 major NCs were detected, while in the second cycle, only one major NC was detected. The average number of major NCs of the first MAs (0.27) was almost equal to the average of the following SAs of the first cycle (0.31), with a higher average in the third SA (Table 2).

The type of assessment influenced the grade of NCs as well as the method of detection. The significance of the differences between the NCs (grade, method of detection, and references to the FSC principles) and audit type was assessed by applying the KruskalWallis test. NCs were identified by auditors through documentation verification (43.6\%), field checks (51.8\%), and by interviewing people affected by or involved in the activity of the audited entity (4.4\%).

Our results pointed out that the type of assessment also influenced the standard reference. Significant differences (for $p=0.01$ ) were identified in the case of principles 5, 6, and 9 (Table 3), with the higher average number of NCs detected in the MAs. Significant differences (for $p=0.05$ ) were also found in the case of document verification, FSC prin- 
ciple 4, and FSC principle 8 (Table 3). It means that for these FSC principles, the type of assessment differed.

Table 3. Analysis of the NCs detected according to the type of assessment.

\begin{tabular}{|c|c|c|c|c|c|}
\hline Variable & Mean & $\begin{array}{c}\text { Standard } \\
\text { Deviation }\end{array}$ & $\begin{array}{c}\text { Main } \\
\text { Assessment }\end{array}$ & Reassessment & Surveillance \\
\hline Minor & 4.10 & 4.23 & $8.35 * *$ & $2.62 * *$ & $2.72 * *$ \\
\hline Major & 0.24 & 0.71 & 0.27 & 0.12 & 0.24 \\
\hline Document verification & 1,89 & 3.28 & $4.09 *$ & $1.50 *$ & $1.15^{*}$ \\
\hline Field checks & 2,26 & 2.32 & $4.23 * *$ & $1.12^{* *}$ & $1.66^{* *}$ \\
\hline Interviews & 0,19 & 0.46 & 0.35 & 0.12 & 0.14 \\
\hline P1: Compliance with laws and FSC principles & 0.25 & 0.44 & 0.35 & 0.25 & 0.21 \\
\hline P2: Tenure and use rights and responsibilities & 0.02 & 0.14 & 0.04 & 0.00 & 0.01 \\
\hline P3: Indigenous peoples' rights & 0.01 & 0.01 & 0.00 & 0.00 & 0.01 \\
\hline P4: Community relations and worker's rights & 0.92 & 1.20 & $1.77 *$ & $0.62 *$ & $0.65 *$ \\
\hline P5: Benefits from the forest & 0.19 & 0.51 & $0.42 * *$ & $0.00 * *$ & $0.13^{* *}$ \\
\hline P6: Environmental impact & 1.82 & 2.17 & $3.81 * *$ & $1.12 * *$ & $1.17^{* *}$ \\
\hline P7: Management plan & 0.48 & 0.93 & 0.77 & 0.50 & 0.37 \\
\hline P8: Monitoring and assessment & 0.45 & 0.90 & $0.85 *$ & 0.12 * & $0.34 *$ \\
\hline P9: Maintenance of high conservation value forests & 0.25 & 0.66 & $0.61 * *$ & $0.12 * *$ & $0.13^{* *}$ \\
\hline Total & 4.34 & 4.51 & $8.61^{* *}$ & $2.75^{* *}$ & $2.96^{* *}$ \\
\hline
\end{tabular}

Note: The significance of the differences was calculated by applying the Kruskal-Wallis test for those related with the type of assessment.

* Significant differences for $p=0.05$ and ${ }^{* *}$ significant differences for $p=0.01$.

There were 49 audits undertaken with teams that included foreign auditors. In these audits, the average number of identified NCs was higher (Table 4), with this factor having a clearer influence on the number and type of NCs. It is worth underlining that, during these audits, significantly more NCs were identified-21 out of the 25 major NCs identified during all 56 audits.

Moreover, there were more NCs identified by field checks and NCs related to the principles 5, 6, and 9 of the standard (Table 4). Witnessing the audits by ASI representatives is not usual-the ASI witnesses were present in only 4 out of the 105 audits. More major NCs were identified during the assessments performed in the presence of ASI assessor (Table 4).

\subsection{Correlation Analysis of the Number of NCs Detected in the Audits}

The correlations between the number of minor, major, and total NCs, and the audited entity variables as well as the audit process variables were tested. For the relationship between year of certification and the number of NCs, the correlation indexes were significant for the number of minor and total NCs. The year of certification for audited entities was associated with more NCs identified by documentation verification and field checks and also with more NCs under principles 5, 6, and 9 (Table 5). The certified area correlated with the total number of NCs, especially with the number of major NCs. The number of NCs identified by document verification was greater for larger certified forest areas. The correlation with the certified forest area was significant for NCs related to principles 4, 6, and 9, and the type of assessment was strongly correlated with the number of minor and total NCs (correlation indexes of 0.54 and 0.55 , respectively) (Table 5).

The type of assessment influenced the number and type of NCs and the standard reference. In the MA reports, more NCs were identified by all verification means: document verification, field checks, and interviews. In addition, there were more NCs related to principles 4, 5, 6, 8, and 9. In longer audits, more minor and major NCs were detected, mainly more NCs related to principles $4,5,6$, and 9 . 
Table 4. Analysis of the NCs identified according to the participation of foreign members and ASI witnesses in the auditing team.

\begin{tabular}{|c|c|c|c|c|}
\hline Variable & No Foreign Auditor Members & Foreign Auditor Members & No ASI Witnesses & ASI Witnesses \\
\hline Minor NC & 3.56 & 4.78 & 4.06 & 5.25 \\
\hline Major NC & $0.07 * *$ & $0.43 * *$ & $0.20 *$ & $1.25 *$ \\
\hline Document check & 1.77 & 2.04 & 1.85 & 2.25 \\
\hline Field & $1.64^{* *}$ & $2.96^{* *}$ & 2.19 & 4.00 \\
\hline Interviews & 0.18 & 0.20 & 0.19 & 0.25 \\
\hline Principle 1 & 0.25 & 0.24 & $0.23 *$ & $0.75 *$ \\
\hline Principle 2 & 0.02 & 0.02 & 0.02 & 0.00 \\
\hline Principle 3 & 0.02 & 0.00 & 0.01 & 0.00 \\
\hline Principle 4 & 0.73 & 1.14 & $0.87 *$ & 2.50 * \\
\hline Principle 5 & $0.07 *$ & 0.33 * & 0.19 & 0.25 \\
\hline Principle 6 & $1.30^{* *}$ & $2.41^{* *}$ & 1.81 & 2.00 \\
\hline Principle 7 & 0.54 & 0.41 & 0.48 & 0.25 \\
\hline Principle 8 & 0.56 & 0.33 & 0.45 & 0.50 \\
\hline Principle 9 & 0.11 * & $0.41 *$ & 0.24 & 0.50 \\
\hline Total & $3.59 *$ & $5.20 *$ & 4.26 & 6.50 \\
\hline
\end{tabular}

Note: Significance of the differences has been calculated by applying Mann-Whitney $U$ tests for the analysis related to the participation of foreign members and ASI witnesses. * Significant differences for $p=0.05$ and ${ }^{* *}$ significant differences for $p=0.01$.

Table 5. Correlation analysis of the number of NCs related to certification year, certified area, main assessment, number of audit days, number of auditors, number of foreign auditors, and ASI witness participation.

\begin{tabular}{|c|c|c|c|c|c|c|c|}
\hline No. of NCs & $\begin{array}{c}\text { Certification } \\
\text { Year }\end{array}$ & $\begin{array}{c}\text { Certified } \\
\text { Area }\end{array}$ & $\begin{array}{c}\text { Main } \\
\text { Assessment }\end{array}$ & Days & $\begin{array}{c}\text { No. of } \\
\text { Auditors }\end{array}$ & $\begin{array}{l}\text { Foreign } \\
\text { Members }\end{array}$ & $\begin{array}{c}\text { ASI } \\
\text { Witnesses }\end{array}$ \\
\hline Average per report & 7.92 & 128,322 & 0.25 & 3.17 & 2.12 & 0.53 & 0.04 \\
\hline Standard deviation & 2.47 & 440,261 & 0.43 & 0.99 & 1.16 & 0.62 & 0.19 \\
\hline Minor & $0.35^{* *}$ & 0.18 & $0.54^{* *}$ & $0.25^{* *}$ & $0.26^{* *}$ & 0.21 * & 0.05 \\
\hline Major & 0.01 & $0.43 * *$ & 0.02 & $0.48^{* *}$ & 0.17 & $0.32 * *$ & $0.28^{* *}$ \\
\hline Document verification & 0.24 * & $0.33^{* *}$ & $0.308^{* *}$ & $0.36^{* *}$ & 0.10 & 0.13 & 0.02 \\
\hline Field checks & $0.32 * *$ & 0.00 & $0.49 * *$ & 0.10 & $0.37 * *$ & $0.30 * *$ & 0.15 \\
\hline Interviews & -0.02 & 0.01 & $0.19 *$ & 0.01 & 0.08 & 0.01 & 0.03 \\
\hline Principle 1 & 0.15 & -0.01 & 0.12 & 0.07 & 0.19 & 0.00 & $0.21 *$ \\
\hline Principle 2 & 0.06 & -0.04 & 0.08 & -0.02 & $0.23 *$ & -0.10 & -0.03 \\
\hline Principle 3 & 0.00 & -0.03 & -0.06 & -0.02 & 0.07 & 0.08 & -0.02 \\
\hline Principle 4 & $0.25^{* *}$ & 0.21 * & $0.43^{* *}$ & $0.19^{*}$ & $0.35 * *$ & $0.25 * *$ & 0.24 * \\
\hline Principle 5 & 0.21 * & 0.11 & $0.26^{* *}$ & 0.20 * & 0.22 * & 0.22 * & 0.02 \\
\hline Principle 6 & $0.32^{* *}$ & 0.245 * & $0.53^{* *}$ & $0.30^{* *}$ & $0.26^{* *}$ & 0.32 * & -0.02 \\
\hline Principle 7 & 0.06 & 0.08 & 0.18 & 0.10 & 0.04 & -0.03 & -0.05 \\
\hline Principle 8 & 0.22 * & 0.12 & $0.26^{* *}$ & 0.14 & -0.08 & -0.09 & 0.01 \\
\hline Principle 9 & 0.23 * & 0.25 ** & $0.33^{* *}$ & $0.40^{* *}$ & 0.10 & 0.24 * & 0.08 \\
\hline NCs & $0.34^{* *}$ & 0.25 * & $0.55^{* *}$ & $0.31^{* *}$ & $0.27 * *$ & 0.25 * & 0.10 \\
\hline
\end{tabular}

* Significant correlations for $p=0.05$ and ${ }^{* *}$ significant correlations for $p=0.01$.

The auditing period as well as the number of auditors in the auditing teams had significant influence on the grade of resulted NCs as well as on the standard reference (principles). The number of NCs identified by document verification was strongly correlated with the number of auditing days. With bigger audit teams, more NCs were detected; specifically, more minor NCs and NCs related to principles 2, 4, 5, and 6. In addition, more NCs were identified during the field checks by teams with more auditors. There were significant correlations between the number of foreign auditors in the audit team and the number of minor, major, and total NCs (Table 5). The number of NCs identified by field checks was greater if there were more foreign auditors in the audit team. In this case, there were more identified NCs related to principles 4, 5, 6, and 9 (Table 5). The participation of the ASI witnesses was not usual and the sample size must be taken into consideration 
in the generalization of the results. The greatest influence of the participation of the ASI witnesses in the audit team was on the number of major NCs, but it was not significant in terms of the minor and the total NCs. Moreover, there were correlations with NCs related to principles 1 and 4 .

\subsection{Regression Analysis of the Number of Minor and Major NCs Detected in the Audits}

All the regressions were significant for $p=0.01$, and $R^{2}$ values were 0.67 for minor NCs, 0.35 for major NCs, and 0.66 for the total number of NCs per audit (Table 6). The values of $R^{2}$ were more than acceptable considering the complexity of the study, the number of independent variables in each regression, the significance of the $\beta$ coefficients in the relevant regressions, and the number of cases used in the analysis [57]. In the first step of the regression, for the number of minor NCs, the year of certification for audited entities explained $54.4 \%$ of the variance, but in the second step, it was excluded from the regression because of the introduction of the variables: main assessment and number of auditing days. This step discarded a potential bias caused by these variables. The variable main assessment $\left(0.48^{* *}\right)$ and the number of auditing days $\left(0.45^{* *}\right)$ had the greatest coefficients in the second step of the regression (Table 6).

Table 6. Regression analysis of the number of NCs detected in the audits.

\begin{tabular}{|c|c|c|c|c|c|c|}
\hline \multirow[t]{2}{*}{ Variables } & \multicolumn{2}{|c|}{ Number of Minor NCs } & \multicolumn{2}{|c|}{ Number of Major NCs } & \multicolumn{2}{|c|}{ Total Number of NCs } \\
\hline & Step 1 & Step 2 & Step 1 & Step 2 & Step 1 & Step 2 \\
\hline \multicolumn{7}{|l|}{ Audited entity variables } \\
\hline Year of certification for audited entities & $0.74^{* *}$ & & $0.20 *$ & 0.01 & $0.69 * *$ & \\
\hline Certified area & & & $0.41 * *$ & $0.43^{* *}$ & 0.14 * & \\
\hline \multicolumn{7}{|l|}{ Audit process variables } \\
\hline Main assessment & & $0.48 * *$ & & - & & $0.42 * *$ \\
\hline Number of days & & $0.45^{* *}$ & & & & $0.51 * *$ \\
\hline Number of auditors & & - & & - & & - \\
\hline Foreign members & & - & & - & & - \\
\hline ASI witness assessment & & - & & $0.29 * *$ & & - \\
\hline \multicolumn{7}{|l|}{ Model information } \\
\hline$R^{2}$ & 0.54 & 0.67 & 0.26 & 0.35 & 0.56 & 0.66 \\
\hline $\mathrm{F}$ for the regression & $123.98 * *$ & $104.56^{* *}$ & $18.46^{* *}$ & $17.99 * *$ & $66.19^{* *}$ & $101.59 * *$ \\
\hline$F$ for the step & $123.98^{* *}$ & $104.56^{* *}$ & $11.43^{* *}$ & $18.58^{* *}$ & $66.19^{* *}$ & $101.59 * *$ \\
\hline
\end{tabular}

* Significant regressions and indexes for $\alpha=0.05$ and ${ }^{* *}$ significant regressions and indexes for $\alpha=0.01$.

In the regression for the number of major NCs, the certification year of the audited entity $\left(0.20^{*}\right)$ and certified forest area $\left(0.41^{* *}\right)$ were significantly correlated with the dependent variable, in the first step, explaining $26.4 \%$ of the variance. In the second step, the unique new variable was the ASI witness participation $\left(0.29^{* *}\right)$, while the certified forest area remained significant $\left(0.43^{* *}\right)$.

In the regression for the total number of NCs, the correlations with the year of certification $\left(0.69^{* *}\right)$ and area $\left(0.14^{*}\right)$ were significant in the first step, explaining $56.2 \%$ of the variance. However, in the second step, the only significant variables were main assessment $(0.42 * *)$ and number of days $(0.51 * *)$. They explained $66.4 \%$ of the variance (Table 6$)$. Regarding the influence of the independent variables on the number of NCs, the analysis confirmed that the year of certification was associated with a greater number of NCs. In the first step of the regression analysis for the case of minor, major, and total NCs, this association was clearly identified. Moreover, for the case of minor and total NCs, the variance explained by the regression models and the $\beta$ coefficients in the regression were rather high (Table 6). 


\section{Discussion}

The regression and correlation analysis supported the association between the certified area and the number of major and total NCs, confirming the findings of other studies $[26,53]$. In the assessment of a larger certified forest area, a greater number of major NCs were identified. The correlation between the certified area and the number of NCs may be explained by the magnitude of the management issues and the multitude of possible situations that can appear in the field checks. Similarly, the analysis shows that the longer the period since audited entities were certified in a certain country/region, the lower the number of NCs; this can be explained by having in mind the learning curve and the rigorous records required by FSC certification.

The analysis also indicates that the number of NCs was influenced by the type of assessment. This finding contradicts previous works in the literature. For example, in Indonesia, Hermudananto [26] analyzed 933 NCs between 2001 and 2016 and showed that the average number of correction actions requests issued did not vary with the type of assessment or certification body. Nevertheless, we need to consider the fact that the FSC procedure requires a sampling approach for the SAs, whilst the MAs are performed through a comprehensive verification including all requirements. This may be one of the causes that determined the higher number of NCs identified during MAs.

The FSC procedures and requirements provide very detailed rules in terms of audit team and auditing time requirements, thus acknowledging that subjectivity can be an issue while trying to reduce it. Still, as a novelty among forest certification-related studies, the findings of the present research indicate that both audit team composition and the number of auditing days had significant influence on the number of identified NCs. The research results indicate that the number of days was positively related to the identification of minor and major NCs (for a 0.01 significance level). This significance level was retained in the association between the number of days and the NCs identified by document verification and field checks. The number of auditors influenced the number of total and minor NCs-if there were more auditors involved, there was a greater number of minor and total NCs. Specifically, in the field checks, this relation was confirmed. Nevertheless, this association was not confirmed for the case of major NCs. There were positive correlations between the presence of foreign members in the audit team and the number of minor and major NCs identified, especially for the NCs that were identified by field checks. The participation of the ASI witnesses was positively related to the major NC identification.

The methodology had certain limitations, as the research presented in this paper only analyzed the Romanian case. Moreover, the analysis was based only on the information recorded in public official FSC assessment records including only a few procedural factors, and therefore only these factors were included in the analysis: type of assessment, auditing days, audit team members, etc. With this, new lines of research can be identified, addressing also socio-economic or institutional contextual factors such as economic trends, policies, land ownership, forest type, logging volume, or number of employees. It is obvious that every assessment has numerous particularities that depend on the decision power of the auditing team. The audits of forest certification schemes are based on samples-some findings will not be traced by auditors. Regarding the NCs, no analysis on description (or categories) was performed since the focus was only on procedural aspects. Another limitation can be identified in the reduced number of reports for ASI-witnessed assessments; therefore, the conclusions regarding the influence of the ASI witness presence on the number of NCs are of limited relevance.

\section{Conclusions}

The empirical analysis of all the 105 audit reports drafted by the accredited thirdparty certifiers for the FSC scheme in Romania sheds light on procedural factors that have significant influence on the characteristics of NCs identified by FSC third party audits.

This study contributes to the relatively limited scholarly literature focused on the outcomes and the procedural factors of the external audits in forest management certification. 
Our research offers empirical evidence that certain procedural factors such as the type of assessment, the auditing period, or the features of the auditing teams have a significant influence on the auditing process outcomes: number and grade of non-conformities, standard references, or methods of NC detection. It also offers indications regarding the effectiveness of the FSC procedures and guidelines in providing reliability of the forest certification assessments. Similarly, this study also contributes to the broader scholarly research line focused on the quality of the external audits of the certifiable standards for Quality and Environmental Management [58,59].

All forest certification schemes are putting a large amount of emphasis on the precision of the auditing procedures and instructions. By pointing out the issue of the effectiveness of such procedures in assuring the quality of the certification assessments, the present study is opening an interesting line of research. The causes that can influence the impact of procedural factors on the results of certification assessments must be carefully analyzed, aiming at an improvement of the certification procedures.

Author Contributions: Conceptualization, A.-F.H., B.P., and I.V.A.; methodology, A.-F.H., B.P., and I.H.-S.; software, G.A.-L.; validation, G.A.-L., O.B., B.P., and A.-F.H.; formal analysis, G.A.-L.; investigation, G.A.-L., A.-I.N., and A.-F.H.; writing-original draft preparation, A.-F.H., I.H.-S., B.P., and A.-I.N.; writing-review and editing, B.P., I.H.-S., O.B., and I.V.A. All authors have read and agreed to the published version of the manuscript.

Funding: This research was funded by Transylvania University of Brasov.

Acknowledgments: The authors would like to sincerely thank to the editor and the anonymous reviewers for their valuable insights.

Conflicts of Interest: The authors declare no conflict of interest.

\section{References}

1. Florian, D.; Dalla Vecchia, I.; Masiero, M. FSC ${ }^{\circledR}$ Forest Management Certification. In Forest Management Auditing: Certification of Forest Products and Services; Routledge: Abingdon, UK, 2018.

2. Rametsteiner, E.; Simula, M. Forest certification-An instrument to promote sustainable forest management? J. Environ. Manag. 2003, 67, 87-98. [CrossRef]

3. Ebeling, J.; Yasué, M. The effectiveness of market-based conservation in the tropics: Forest certification in Ecuador and Bolivia. J. Environ. Manag. 2009, 90, 1145-1153. [CrossRef] [PubMed]

4. Suryani, A.N.; Shahwahid, H.M.; Fauzi, P.A.; Alias, R.; Vlosky, R.P. Assessment of chain-of-custody certification costs for sawnwood manufacturers in Peninsular Malaysia. JTFS 2011, 23, 159-165.

5. Halalisan, A.F.; Marinchescu, M.; Popa, B.; Abrudan, I.V. Chain of Custody certification in Romania: Profile and perceptions of FSC certified companies. Int. For. Rev. 2013, 15, 305-314. [CrossRef]

6. Basso, V.M.; Jacovine, L.A.G.; Nardelli, A.M.B.; Alves, R.R.; da Silva, E.; Silva, M.L.; Andrade, B.G. FSC forest management certification in the Americas. Int. For. Rev. 2018, 20, 31-42. [CrossRef]

7. Maletz, O.; Tysiachniouk, M. The effect of expertise on the quality of forest standards implementation: The case of FSC forest certification in Russia. For. Policy Econ. 2009, 11, 422-428. [CrossRef]

8. Roberge, A.; Bouthillier, L.; Boiral, O. The influence of forest certification on environmental performance: An analysis of certified companies in the province of Quebec (Canada). Can. J. For. Res. 2011, 41, 661-668. [CrossRef]

9. Halalisan, A.F.; Popa, B.; Heras-Saizarbitoria, I.; Ioras, F.; Abrudan, I.V. Drivers, perceived benefits and impacts of FSC Chain of Custody Certification in a challenging sectoral context: The case of Romania. Int. For. Rev. 2019, 21, 195-211. [CrossRef]

10. Trolliet, F.; Vogt, M.; Kleinschroth, F. How does FSC certification of forest management benefit conservation of biodiversity? In Sustainability Certification Schemes in the Agricultural and Natural Resource Sectors: Outcomes for Sociey and the Environment; Routledge: Abingdon, UK, 2019; pp. 93-110.

11. FSC. Facts \& Figures, Forest Stewardship Council. Available online: https://fsc.org/en/facts-figures (accessed on 3 October 2020).

12. FSC. General Requirements for FSC Accredited Certification Bodies (FSC-STD-20-001 Standard V4-0 EN). Available online: https: / fsc.org/en/document-centre/documents/resource/280 (accessed on 3 March 2020).

13. PEFC. Programme for Endorsement of Forest Certification Schemes. Available online: www.pefc.org (accessed on 20 January 2021).

14. Espach, R. Private regulation amid public disarray: An analysis of two private environmental regulatory programs in Argentina. Bus. Politics 2005, 7, 1-36. [CrossRef] 
15. Gulbrandsen, L.H. Dynamic governance interactions: Evolutionary effects of state responses to non-state certification programs. Regul. Gov. 2014, 8, 74-92. [CrossRef]

16. Paluš, H.; Parobek, J.; Vlosky, R.P.; Motik, D.; Oblak, L.; Jošt, M.; Glavonjić, B.; Dudík, R.; Wanat, L. The status of chain-of-custody certification in the countries of Central and South Europe. Eur. J. Wood and Wood Prod. 2018, 76, 699-710. [CrossRef]

17. Paluš, H.; Parobek, J.; Šulek, R.; Lichý, J.; Šálka, J. Understanding Sustainable Forest Management Certification in Slovakia: Forest Owners' Perception of Expectations, Benefits and Problems. Sustainability 2018, 10, 2470. [CrossRef]

18. Galati, A.; Gianguzzi, G.; Tinervia, S.; Crescimanno, M.; La Mela Veca, D.S. Motivations, adoption and impact of voluntary environmental certification in the Italian Forest based industry: The case of the FSC standard. For. Policy Econ. 2017, 83, 169-176. [CrossRef]

19. Maesano, M.; Ottaviano, M.; Lidestav, G.; Lasserre, B.; Matteucci, G.; Scarascia Mugnozza, G.; Marchetti, M. Forest certification map of Europe. iForest 2018, 11, 526-533. [CrossRef]

20. Nebel, G.; Quevedo, L.; Bredahl Jacobsen, J.; Helles, F. Development and economic significance of forest certification: The case of FSC in Bolivia. For. Policy Econ. 2005, 7, 175-186. [CrossRef]

21. Moore, S.E.; Cubbage, F.; Eicheldinger, C. Impacts of Forest Stewardship Council (FSC) and Sustainable Forestry Initiative (SFI) Forest Certification in North America. J. For. 2012, 110, 79-88. [CrossRef]

22. Klarić, K.; Greger, K.; Klarić, M.; Andrić, T.; Hitka, M.; Kropivšek, J. An exploratory assessment of FSC chain of custody certification benefits in Croatian wood industry. Drv. Ind. Znan. Čas. Pitanja Drv. Tehnol. 2016, 67, 241-248. [CrossRef]

23. Karsenty, A. Certification of tropical forests: A private instrument of public interest? A focus on the Congo Basin. For. Policy Econ. 2019, 106, 101974. [CrossRef]

24. Ehrenberg-Azcárate, F.; Peña-Claros, M. Twenty years of forest management certification in the tropics: Major trends through time and among continents. For. Policy Econ. 2020, 111, 102050. [CrossRef]

25. Blackman, A.; Raimondi, A.; Cubbage, F. Does forest certification in developing countries have environmental benefits? Insights from Mexican corrective action requests. Int. For. Rev. 2017, 19, 247-264. [CrossRef]

26. Hermudananto; Romero, C.; Ruslandi; Putz, F.E. Analysis of corrective action requests from Forest Stewardship Council audits of natural forest management in Indonesia. For. Policy Econ. 2018, 96, 28-37. [CrossRef]

27. Piketty, M.-G.; Garcia Drigo, I. Shaping the implementation of the FSC standard: The case of auditors in Brazil. For. Policy Econ. 2018, 90, 160-166. [CrossRef]

28. Rafael, G.C.; Fonseca, A.; Jacovine, L.A.G. Non-conformities to the Forest Stewardship Council (FSC) standards: Empirical evidence and implications for policy-making in Brazil. For. Policy Econ. 2018, 88, 59-69. [CrossRef]

29. Dick, G.P.M.; Heras, I.; Casadesús, M. Shedding light on causation between ISO 9001 and improved business performance. Int. J. Oper. Prod. Manag. 2008, 28, 687-708. [CrossRef]

30. Heras, I.; Arana, G. Alternative models for environmental management in SMEs: The case of Ekoscan vs. ISO 14001. J. Clean. Prod. 2010, 18, 726-735. [CrossRef]

31. Heras-Saizarbitoria, I.; Dogui, K.; Boiral, O. Shedding light on ISO 14001 certification audits. J. Clean. Prod. 2013, 51, 88-98. [CrossRef]

32. Sampaio, P.; Saraiva, P.; Guimarães Rodrigues, A. A classification model for prediction of certification motivations from the contents of ISO 9001 audit reports. Total. Qual. Manag. Bus. Excell. 2010, 21, 1279-1298. [CrossRef]

33. Boiral, O. Managing with ISO systems: Lessons from practice. LRP 2011, 44, 197-220. [CrossRef]

34. Heras-Saizarbitoria, I.; Boiral, O. ISO 9001 and ISO 14001: Towards a research agenda on management system standards. IJMR 2013, 15, 47-65. [CrossRef]

35. Biazzo, S. The new ISO 9001 and the problem of ceremonial conformity: How have audit methods evolved? Total Qual. Manag. Bus. Excell. 2005, 16, 381-399.

36. Karapetrovic, S.; Willborn, W. Quality assurance and effectiveness of audit systems. Int. J. Qual. Reliab. Manag. 2000, 17, 679-703. [CrossRef]

37. Chiarini, A.; Vagnoni, E. A proposed audit pattern for the shop-floor processes in TQM, Lean Six Sigma and ISO 9001 environments. IJSOM 2014, 18, 159. [CrossRef]

38. Dahlgaard-Park, S.M. The SAGE Encyclopedia of Quality and the Service Economy; SAGE Publications: Sauzend Oaks, CA, USA, 2015.

39. McDermott, C.L. Trust, legitimacy and power in forest certification: A case study of the FSC in British Columbia. Geoforum 2012, 43, 634-644. [CrossRef]

40. Bernstein, S. Legitimacy in global environmental governance. J. Int'l L Int'l Rel. 2004, 1, 139.

41. Dogui, K.; Boiral, O.; Heras-Saizarbitoria, I. Audit fees and auditor independence: The case of ISO 14001 certification. Int. J. Audit. 2014, 18, 14-26. [CrossRef]

42. Power, M. Evaluating the Audit Explosion. Law Policy 2003, 25, 185-202. [CrossRef]

43. Bamber, E.M.; Iyer, V.M. Auditors' identification with their clients and its effect on auditors' objectivity. Audit. J. Pract. Theory 2007, 26, 1-24. [CrossRef]

44. Kouakou, D.; Boiral, O.; Gendron, Y. ISO auditing and the construction of trust in auditor independence. Account. Audit. Account. J. 2013, 26, 1279-1305. [CrossRef] 
45. Dror, I.E.; Pierce, M.L. ISO standards addressing issues of bias and impartiality in forensic work. J. Forensic Sci. 2020, 65, 800-808. [CrossRef]

46. FSC. Forest Management Evaluations (FSC-STD-20-007 Standard V3-0 EN). Available online: https:/ / fsc.org/en/documentcentre/documents/resource/279 (accessed on 10 October 2020).

47. FSC. FSC Directive on FSC Forest Management Evaluations (FSC-DIR-20-007). Available online: https:// fsc.org/en/documentcentre/documents/resource/394 (accessed on 10 October 2020).

48. ASI. Assurance Services International-ASI. Available online: https://www.asi-assurance.org/s/ (accessed on 14 October 2020).

49. Dragoi, M.; Popa, B.; Blujdea, V. Improving communication among stakeholders through ex-post transactional analysis-Case study on Romanian forestry. For. Policy Econ. 2011, 13, 16-23. [CrossRef]

50. Abrudan, I.V. A decade of non-state administration of forests in Romania: Achievements and challenges. Int. For. Rev. 2012, 14, 275-284. [CrossRef]

51. Bouriaud, L.; Marzano, M. Conservation, Extraction and Corruption: Is sustainable Forest Management Possible in Romania? In Natural Resources Extraction and Indigenous Livelihoods. Development Challenges in an Era of Globalization; Routledge: New York, NY, USA, 2014; pp. 221-241. ISBN 978-1-4094-3777-2.

52. Popa, B.; Niță, M.D.; Hălălișan, A.F. Intentions to engage in forest law enforcement in Romania: An application of the theory of planned behavior. For. Policy Econ. 2019, 100, 33-43. [CrossRef]

53. Halalisan, A.F.; Ioras, F.; Korjus, H.; Avdibegovic, M.; Maric, B.; Malovrh, S.P.; Abrudan, I.V. An analysis of forest management non-conformities to FSC standards in different European countries. Not. Bot. Horti Agrobot. Cluj-Napoca 2016, 44, 634-639. [CrossRef]

54. Buliga, B.; Nichiforel, L. Voluntary forest certification vs. stringent legal frameworks: Romania as a case study. J. Clean. Prod. 2019, 207, 329-342. [CrossRef]

55. Nichiforel, L.; Keary, K.; Deuffic, P.; Weiss, G.; Thorsen, B.J.; Winkel, G.; Avdibegović, M.; Dobšinská, Z.; Feliciano, D.; Gatto, P.; et al. How private are Europe's private forests? A comparative property rights analysis. Land Use Policy 2018, 76, 535-552. [CrossRef]

56. FSC Public Search. Available online: https://info.fsc.org/ (accessed on 20 June 2020).

57. Faul, F.; Erdfelder, E.; Buchner, A.; Lang, A.G. Statistical power analyses using G* Power 3.1: Tests for correlation and regression analyses. Behav. Res. Methods 2009, 41, 1149-1160. [CrossRef]

58. Boiral, O.; Heras-Saizarbitoria, I.; Brotherton, M.-C. Assessing and improving the quality of sustainability reports: The auditors' perspective. J. Bus. Ethics 2019, 155, 703-721. [CrossRef]

59. Boiral, O.; Heras-Saizarbitoria, I.; Brotherton, M.-C.; Bernard, J. Ethical issues in the assurance of sustainability reports: Perspectives from assurance providers. J. Bus. Ethics 2019, 159, 1111-1125. [CrossRef] 